\title{
EPIPHYTIC LICHENS IN THE TOWN OF ZVEČAN AND THEIR BIOINDICATIOR S VALUE
}

\author{
GORDANA ALEKSIĆ ${ }^{1, \star}$, SLAVIŠA STAMENKOVIĆ ${ }^{2}$, SVETLANA RISTIĆ $^{2}$, MARIJA MARKOVIĆ ${ }^{2}$ \\ ${ }^{1}$ Faculty of Natural Sciences and Mathematics, University of Priština, Kosovska Mitrovica, Serbia \\ ${ }^{2}$ Faculty of Sciences and Mathematics, University of Niš, Niš, Serbia
}

\begin{abstract}
This paper treats the long-term changes in area of the "lichen desert" of town Zvečan. Comparison of results obtained in 1926, when 67 lichen species where present, through the results in 1983 and 1988 when the "lichen desert", low or no lichen diversity was established because of the air pollution, with investigations carried out in 2014,16 lichen species were identified. The "lichen desert" is no existing any more. The main reason that the lichens are present now is termination of operation of the "Trepča" company and cessation primary pollutants emissions. Using lichens as a bioindicators in this investigation it was established the average air pollution, which is lichen "struggle zone",meaning increase air quality.
\end{abstract}

Keywords: "Lichen desert", Lichen "struggle zone", Bio-indicators, Air quality, Zvečan

\section{INTRODUCTION}

Knowledge of lichens, the ecology of certain species and the legitimacy of their distribution in urban areas is important for science for theoretical and applicative aspect.

Data on the works of Androssovsky and Szatal (1926) are available about the lichen in the area of Kosovska Mitrovica (Kušan, 1953). Beqiri et al. (1983) have done the lichenological zone of the Kosovska Mitrovica region, while Murati et al. (1988) and his associates investigated the efect of polluted air on the lichens development in this area.

After these lichens investigations 26 years have passed. During this time, there have been changes in urban and industrial terms. Kosovska Mitrovica has developed into one of the larger cities in the region. In 1999, the base of development and source of extreme environmental pollution of the area of Kosovska Mitrovica (Živić et al., 2014; Živić, 2015), RMHK "Trepčca", stopped working. This has led to a number of social problems, but it has contributed to the improvement of the environment and the recovery of diferent ecosystems (Živić et al., 2008). The enormous emissions of pollutants have ceased, which have deteriorated the living conditions in all aspects (water, air, soil). However, with the termination of operation of the "Trepča", environmental pollutants were not stopped by the secondary pollutants (BabovićJakšić \& Živić, 2008). Deposits containing large quantities of slag produced as a product of lead, zinc, bismuth and other metals metallurgy, followed by trash ore left behind in the flotation of ore, as well as other types of industrial and urban waste, even today deteriorate the environment in Kosovska Mitrovica and Zvečan. However, secondary pollution from the deposits still represent the threat for the human population health (Babović-Jakšić \& Živić, 2008; Babović-Jakšić et al., 2013) and for the whole ecosystem.
One of the ways to control the quality of the environment is the application of bio-indication methods. They are based on the selective response of certain species to specific environmental factors. Jakšić (2013) and Živić (2015) use diferent species of invertebrates to investigate the ecosystems under the influence of pollution. In this sense, the lichens have proven to be good bioindicators for assessing the quality of atmospheric air. This special practical application is able to be used in the assessment of air pollution in urban areas, especially on the increased concentration of $\mathrm{SO}_{2}$ - the main urban pollutant.

Starting from the fact that the lichens in Zvečan is not well known, we have approached theme with the aim of concluding on the basis of the analysis of the diversity and distribution of epiphytic lichen and the air quality in Zvečan. One of the ways to control the quality of the environment is the application of bioindication methods. They are based on the selective response of certain species to specific environmental factors. In this sense, the lichens have proven to be good bio-indicators for assessing the quality of atmospheric air. This special practical application is able to be used in the assessment of air pollution in urban areas, especially on the increased concentration of $\mathrm{SO}_{2}$ - the main urban pollutant. Lichens, show the actual state of air pollution at the place where they live, and in that way they point to a real, long-lasting process of negative impact on people and other living organisms of the given area (Stamenković, 2004).

Starting from the fact that the lichens in Zvečan is not well known, we have approached theme with the aim of concluding on the basis of the analysis of the diversity and distribution of epiphytic lichen and the air quality in Zvečan.

^ Corresponding author: gordanaalekszic@gmail.com 


\section{MATERIALS AND METHODS}

Lichenological material was collected in April 2014. Collection, determination and mapping of epiphytic lichens was carried out in the yard of Elementary School "Vuk Karadžić" in Zvečan. The method used in these investigation is developed by Kirschbaum \& Wirth (1997).

The lichens were observed and determined on six trees of the same woody species, on the surface of $50 \times 20 \mathrm{~cm}$ which is divided into squares of $10 \times 10 \mathrm{~cm}$. This measuring surface is at a height of $1 \mathrm{~m}$ from the surface of the soil on the examined tree. The abundance was determined or each lichen species on all six studied trees.

The sum of the average abundances for all six trees, for each lichen species, is the local index of air quality IAP (Index of Atmospheric Purity). In order to obtain the final result from the obtained value, the frequency of the species Lecanora conizaeoides is taken away, if present on the measuring surface. The IAP is equal to the value obtained. The air quality index was calculated according to the ratio: the sum of frequency frequencies = IAP.

Based on the established diversity of lichens, mapping was performed using lichens as bio-indicators based on the general scale of air quality determination according to IAP values (Conti Cecchetti, 2001) (Table 1).

The identification of the lichen species was done using the keys: Dobson (2011); Wirth (1995), while Index Fungorum was used to determine the nomenclature. The following reagents were used to determine more closely: concentrated HCL, saturated aqueous solution of chlorine lime $\left(\mathrm{CaClO}_{2}\right), 10 \%$ solution of $\mathrm{NaOH}$ in water and alcoholic solution $\mathrm{J}+\mathrm{KJ}$.

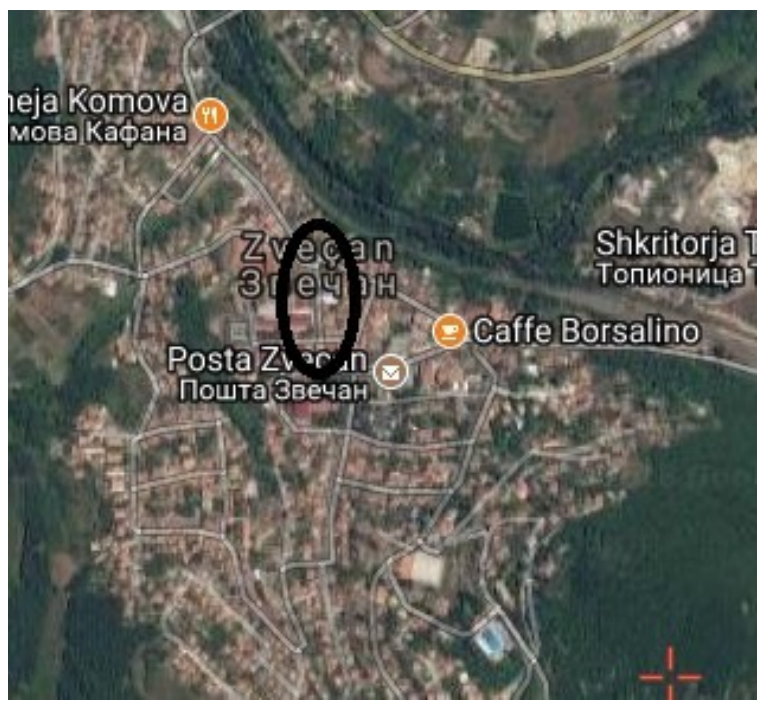

Figure 1. The position of the measuring point is indicated with an ellipse on the map of Zvečan

As a measuring point it was selected the park in the yard of the primary school "Vuk Karadzić" in Zvečan. Two woody species were selected for the substrate under which the investigation was carried out: Aesculus hippocastanum (L.) and Picea abies
(L.) Karsten. Measurement point coordinates are: $42.909818 \mathrm{~N}$; $20.8384488 \mathrm{E} ; \AA=578 \mathrm{~m}$. The position of the measuring point is indicated with an ellipse on the map of Zvečan (Figure 1).

\section{RESULTS AND DISCUSSION}

Field analysis revealed the presence of 16 species of lichens from 11 genera.With crustose thallus type there are four, foliose 11 and a shrubby one lichen species (Table 2).

On the Aesculus hippocastanum, the presence of 11 lichen species was determinate. Present lichens species according to the gradient of decline: Amandinea punctata and Physcia stellaris (100\%), Hypogymnia physodes, Phaeophysia orbicularis, Physcia adscendens, Physconia grisea (83,33\%), Physcia aipolia $(66,67)$, Candelariella xanthostigma and Ramalina fraxinea (50\%), Physcia tenella and Xanthoria parietina (33.33\%) (Table 3).

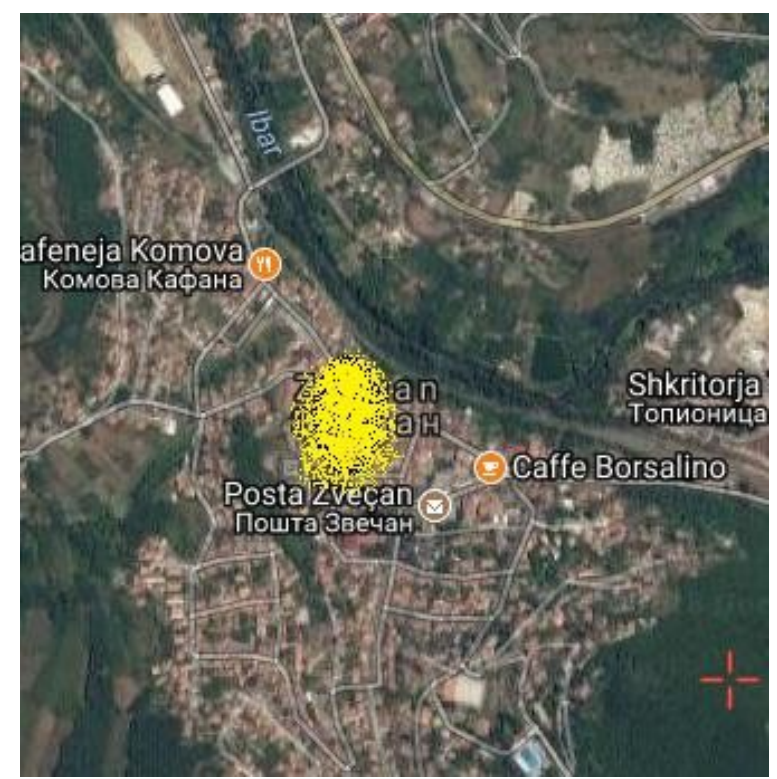

Figure 2. Mapping of the measuring point based on the general scale of air quality determination according to the IAP values (yellow color indicates the average air pollution, the lichen "struggle zone ")

On the Picea abies 10 lichens species have been identified. Present species of lichens according to the gradient of decline: Caloplaca cerina, Melanelixia fuliginosa subsp. glabratula, Physcia adscendens, Physcia aipolia and Physcia tenella (100\%), Physcia stelaris, Xanthoria parietina and Xanthoria polycarpa (83.33\%), Caloplaca cerinella (66.67\%) and Punctelia subrudecta $(50.00 \%)$ (Table 4$)$.

Similarities are in the presence of the species Physcia adscendens, Physcia aipolia, Physcia stellaris, Physcia tenella and Xanthoria parietia on both substrates (Tables 3 and 4).

The diferences are that only at the Aesculus hippocastanum present species: Amandinea punctata, Candelariella xanthostigma, Hypogymnia physodes, Phaeophyscia orbicularis, 
Table 1. General scale of air quality determination according to IAP values (Conti \& Cecchetti, 2001)

\begin{tabular}{|c|c|c|c|c|c|c|}
\hline Polution & Extreme high & Very high & High & Average & Weak & Very weak \\
\hline \multicolumn{7}{|l|}{ Color } \\
\hline IAP & 0 & 12.5 & & 37.5 & & 0.0 \\
\hline Lichens zone of indicators & \multicolumn{2}{|c|}{ "lichen desert" } & \multicolumn{2}{|c|}{ " struggle zone" } & \multicolumn{2}{|c|}{ "normal zone" } \\
\hline
\end{tabular}

Table 2. Identified lichen species and thallus type

\begin{tabular}{|l|c|c|c|}
\hline \multicolumn{1}{|c|}{ Lichen species } & \multicolumn{3}{c|}{ Thallus type } \\
\cline { 2 - 4 } & crustose & foliose & fruticose (shrubby) \\
\hline Amandinea punctat (Hoffm.) Massal. & + & & \\
\hline Caloplaca cerina (Ehrh. ex Hedw) Th. Fr. & + & & \\
\hline Caloplaca cerinella (Nyl.) Flagey & + & & \\
\hline Candelariella xanthostigma (Ach.) Lettau. & + & & \\
\hline Hypogymnia physodes (L.) Nyl. & & + & \\
\hline Melanelixia fuliginosa subsp. glabratula (Lamy) J.R. Laundon, & & + & \\
\hline Phaeophyscia orbicularis (Necker) Moberg & & + & \\
\hline Physcia adscendens (Fr.) H. Olivier. & & + & \\
\hline Physcia aipolia Ehrh. ex Humb.) Furnr. & & + & \\
\hline Physcia stellaris (L.) Nyl. & & + & \\
\hline Physcia tenella (Scop.) DC. & & + & \\
\hline Physconia grisea (Lam.) Poelt. & & + & \\
\hline Punctelia subrudecta (Nyl.) Krog. & & + & \\
\hline Ramalina fraxinea (L.) Ach. & & & \\
\hline Xanthoria parietina (L.) Th. Fr. & & + & \\
\hline Xanthoria polycarpa (Hoffm.) Rieber. & & + \\
\hline
\end{tabular}

Physconia grisea and Ramalina fraxinea while on the Picea abies are not present.

On the Picea abies, the presence of species was established: Caloplaca cerina, Caloplaca cerinella, Melanelixia fuliginosa subsp. glabratula, Punctelia subrudecta and Xanthoria polycarpa, while on the Aesculus hippocastanum are not present.

Comparing the lichen habitat on these two substrates, the lichens are present on the Aesculus hippocastanum, on the tree trunk, while on the Picea abies they are present only on the branches of the trees, but there are no exist on the trunk.

For the mapping of the measuring point using lichens as a bio-indicator, based on a general scale of air quality IAP values, following the used method, only diversity and lichen abundance on the Aesculus hippocastanum can be used. On the measuring surface required by the method, there are no lichens on the Picea abies, the diversity and the abundance are equal to zero (0). On this plant species, lichens are present only on the branches of the trees, not on the trunk. This is the reason for not taking the IAP value on Picea abies for mapping. Therefore, the mapping of the measuring point based on the IAP value on the Aesculus hippocastanum was used.
On the Aesculus hippocastanum, the IAP value is 34.67 , indicating the average air pollution, which is the lichen "struggle zone" (Figure 2).

In 1926, Androssovsky and Szatala identified 18 families of lichens in the region Kosovska Mitrovica and Zvečan, classified in 24 genera and 67 species (Kušan, 1953). In 1983, Beqiri and associates performed the lichenological zone of the Kosovska Mitrovica. They noted in the "lichen desert" zone three species: Lecanora erysibe, Calopa cadecipiens and Candelari vitelina. This zone coincides with the site that was explored by this work.

In the second zone, the "zone of struggle" of the lichens, identified 10 taxa: Xanthoria erysibe, Xanthoria parietina, Physcia ascendes, Lecanora muralis, Candelariella vitelina, Candelariella aurella, Lecidea sp., Caloplaca decipiens, Lecanora pallid, Lecanora subfusca.

This zone coincides to a lesser extent with the research of this investigations, because it covers a wider zone with surrounding, more distant municipalities.In the third, "normal" zone, it was found that species from the family of Usnaceae appeared.

Species which were identified during previous investigations and now: Xanthoria parietina, and Physcia adscendens.

Comparing with earlier research by Murati with associates (1988), when the "lichen desert" was established, the lack of lichen 
Table 3. Lichens diversity, abundance and frequency (\%) on Aesculus hippocastanum

\begin{tabular}{|c|c|c|c|c|c|c|c|c|}
\hline \multirow[t]{2}{*}{ Lichen species } & \multicolumn{7}{|c|}{ number of tree } & \multirow[t]{2}{*}{$\%$} \\
\hline & I & II & III & IV & $\mathrm{V}$ & VI & Average abundance & \\
\hline Amandinea punctata & 6 & 10 & 9 & 6 & 6 & 5 & 7,00 & 100 \\
\hline Candelariella xanthostigma & 1 & 0 & 4 & 0 & 4 & 0 & 1,50 & 50 \\
\hline Hypogymnia physodes & 1 & 0 & 4 & 5 & 5 & 2 & 2,83 & 83,33 \\
\hline Phaeophyscia orbicularis & 10 & 0 & 3 & 8 & 8 & 5 & 5,63 & 83,33 \\
\hline Physcia adscendens & 6 & 0 & 4 & 6 & 7 & 10 & 5,50 & 83,33 \\
\hline Physcia aipolia & 7 & 0 & 0 & 3 & 3 & 1 & 2,33 & 66,67 \\
\hline Physcia stellaris & 10 & 1 & 5 & 9 & 9 & 5 & 6,50 & 100 \\
\hline Physcia tenella & 1 & 0 & 1 & 0 & 0 & 0 & 0,33 & 33,33 \\
\hline Physconia grisea & 1 & 0 & 3 & 2 & 2 & 2 & 1,67 & 83,33 \\
\hline Ramalina fraxinea & 0 & 0 & 2 & 1 & 1 & 0 & 0,67 & 33,33 \\
\hline Xanthoria parietina & 0 & 0 & 1 & 0 & 0 & 3 & 0,67 & 50 \\
\hline Lecanora conizaeoides & & & & & & & 0 & \\
\hline \multicolumn{7}{|c|}{ Index of Atmospheric Purity (sum of frequencies) } & $\sum 34,67$ & \\
\hline
\end{tabular}

Table 4. Lichens diversity, abundance and frequency (\%) on Picea abies

\begin{tabular}{|c|c|c|c|c|c|c|c|c|}
\hline \multirow[t]{2}{*}{ Lichen species } & \multicolumn{7}{|c|}{ number of tree } & \multirow[t]{2}{*}{$\%$} \\
\hline & I & II & III & IV & $\mathrm{V}$ & VI & Average abundance & \\
\hline Caloplaca cerina & 7 & 8 & 5 & 8 & 6 & 4 & 6,33 & 100 \\
\hline Caloplaca cerinella & 0 & 1 & 0 & 1 & 1 & 2 & 0.83 & 66,67 \\
\hline Melanelixia fuliginosa subsp. glabratula & 3 & 4 & 5 & 5 & 6 & 5 & 4.67 & 100 \\
\hline Physcia adscendens & 10 & 10 & 9 & 9 & 10 & 10 & 9.67 & 100 \\
\hline Physcia aipolia & 3 & 5 & 5 & 7 & 6 & 2 & 4.67 & 100 \\
\hline Physcia stellaris & 1 & 1 & 0 & 1 & 2 & 2 & 1.16 & 83,33 \\
\hline Physcia tenella & 6 & 4 & 5 & 8 & 6 & 9 & 6,33 & 100 \\
\hline Punctelia subrudecta & 0 & 0 & 2 & 1 & 1 & 0 & 0,67 & 50 \\
\hline Xanthoria parietina & 2 & 1 & 3 & 0 & 4 & 2 & 2.00 & 83,33 \\
\hline Punctelia subrudecta & 0 & 1 & 3 & 1 & 4 & 2 & 1.83 & 83,33 \\
\hline \multicolumn{7}{|c|}{ Index of Atmospheric Purity (sum of frequencies) } & $\sum 38,16$ & \\
\hline
\end{tabular}

diversity, this investigation identified 16 species at this site. This indicates an increase in diversity, or improvement of habitats.

The reason for this is the termination of "Trepča" company and no primary emissions of pollutants.

\section{CONCLUSION}

Biomonitoring was carried out in the Park site in the yard of primary school "Vuk Karadžić" in Zvečan, April 2014. Two woody species were selected for the substrate under which it was applied: Aesculus hippocastanum and Picea abies. Analyzing the investigated samples, 16 species were identified within 11 genera.

The most common genera are: Physcia, four species ( $P$. stellaris, $P$. adscendens, P. tenella, $P$. aipolia), Caloplaca, two species (C. cerina and C. cerinella), Xanthoria two species (X. parietina and $X$. polycarpa). Other genera are present with one species. Lichens are present on the Aesculus hippocastanum on the tree trunk, while on the Picea abies are present only on the branches of trees, but there are not on the trunk. On the Aesculus hippocastanum, the IAP value is 34.67 , indicating an average air pollution.

Mapping of the measuring point was performed based on the IAP value of the Aesculus hippocastanum.

Using the Picea abies as a substrat, value of the IAP is 38.16. After the "lichen desert" in the year of 1988. in 2014. it was established lichen "struggle zone".

\section{REFERENCES}

Babović-Jakšić, T., Živić, V. N., Stamenković, S., Đikić, A., \& Sretić, L. 2013. The heavy metal influence on the human population in Kosovska Mitrovica. In V International Symposium of Ecologists of Montenegro - The Book of Abstracts and Programme. p. 99.

Babović-Jakšić, T. \& Živić, V. N. 2008. Types of Ekological Projects Implemented by L/NGs in Kosovska Mitrovica from 1999-2008. Natura Montenegrina, 7(3), pp. 125-128. Podgorica, Montenegro. 
Babović-Jakšić, T. \& Živić, V. N. 2008. Female Population in Reproductive Period Awareness Presence and Harmful Influence of Lead in Kosovska Mitrovica. Natura Montenegrina, Podgorica, 7(3), pp. 503-508.

Beqiri, S., Bejtullahu, B., \& Miletic, S. 1983. Ispitivanje zagađenosti vazduha Titove Mitrovice i okoline tokom 1982/83. god. In Simpozijum o stanju, zaštiti i unapređenju čovekove sredine. Zvečan. pp. 153-164.

Conti, M. E. \& Cecchetti, G. 2001. Biological monitoring: lichens as bioindicators of air pollution assessment - a review. Environmental Pollution, 114(3), pp. 471-492. doi:10.1016/s02697491(00)00224-4.

Dobson, F. 2011. Lichens An Illustrated Guide to the British and Irish Species.England: The Richmond Publishing Co. Ltd.

Jakšić, T. 2013. Soil bioindication in the region of Kosovska Mitrovica. PhD degree. University of Pristina, Faculty of Sciences and Mathematics, Kosovska Mitrovica.

Kirschbaum, U. \& Wirth, V. 1997. Les lichens bio-indicators. Paris: Edition Ulmer.

Kušan, F. 1953. Prodromus flore lišaja Jugoslavije.Zagreb: JAZU. Murati, M., Pejčinović, D., \& Hodža, E. 1988. Uticaj onečišćenog vazduha na razvoj lišajeva u području Titove Mitrovice. In Četvrti kongres ekologa Jugoslavije. Ohrid.
Stamenković, S. 2004. Bioindikacija stepena žagađenosti vazduha urbanih sredina korišćenjem lišaja kao bioindikatora - seminar. In .Univerzitet u Beogradu - Biološki fakultet - Institut za botaniku.Botanička bašta „Jevremovac“. pp. 3-5.

Wirth, V. 1995. Die Flechten Baden-Wurttembergs-Teil 1 and 2. Stuttgart: Vergal Ulmer.

Živić, V. N. 2015. Characteristics of macro fauna invertebrates with an overview of the Oligochaete fauna in ecosystems under the influence of the thermal complex "Obilić" thermal power plant. University of Prishtina with dislocated in Kosovska Mitrovica - Faculty of Natural Sciences and Mathematics, pp. $1-155$.

Živić, V. N., Atanacković, A., Milosević, S., \& Milosavljević, M. 2014. The distribution of Astacidae (Decapoda) fauna in Kosovo and Metohija. Water Research and Management, 4(4), pp. 35-40.

Živić, V. N., Vukanić, V., Babović-Jakšić, T., \& Miljanović, B. 2008. Distribution of macrozoobenthos in the tribuataries of river Ibar in the Northern part of Kosovo and Metohija. Natura Montenegrina, 7(2), pp. 401-411. Podgorica, Republic of Montenegro. 